\title{
Ice flow around large obstacles as indicated by basal ice exposed at the margin of the Greenland ice sheet
}

\author{
Peter G. KNIGHT, \\ Department of Geography, Keele University, Keele, Staffordshire ST5 5BG, England \\ DAvid E. Sugden AND Christopher D. MinTy \\ Department of Geography, University of Edinburgh, Edinburgh EH8 9XP, Scotland
}

\begin{abstract}
Spatial variations in the debris-bearing basal ice layer exposed at the ice-sheet margin in West Greenland reflect the geography of basal melting and ice flow around large obstacles close to the margin. This paper demonstrates the character of the basal ice layer, which comprises fine material incorporated in an interior, subglacial environment and coarser material entrained in an ice-marginal environment. We develop an empirical model of ice flow close to a lobate margin of the ice sheet in which ice convergence and divergence, and limited subglacial melting affect the character and distribution of the basal ice at the margin. There is a tendency for the convergence and divergence to thicken the basal layer in lobate areas and to thin it in inter-lobate areas. Under certain circumstances, basal melting may remove much of the layer from beneath the snouts of larger lobes, thus causing the basal layer to be thickest in an intermediate location.
\end{abstract}

\section{INTRODUCTION}

The aim of this paper is to demonstrate the way in which variations in the distribution of the basal-ice layer exposed at the margin of the Greenland ice sheet can be used to identify patterns of subglacial processes. Increasingly detailed understanding of the processes which give rise to specific basal ice phenomena is making it possible to use ice-marginal exposures in this way (Lawson, 1979). For example, Sugden and others (1987), Knight (1987) and Souchez and others (1990) used marginal basal-ice patterns to infer the location of zones of entrainment beneath the Greenland ice sheet, and to distinguish between processes operating in the ice-sheet interior and processes operating close to the margin. As ice-sheet modellers demand increasingly precise field data to test and calibrate their models, relatively inexpensive and convenient sites at the ice-sheet margin can provide useful data about internal processes. However, this depends on our ability to make reliable interpretations of marginal basal-ice observations. Of the basal-ice types that have been described in the literature (see Hubbard and Sharp (1989) and Souchez and Lorrain (1991) for useful reviews), the "clotted-ice" facies seems potentially the most useful for identifying internal processes, but it is also the least thoroughly understood. The first part of this paper discusses the nature of the debris in the clotted-ice facies and how it can be used as an indicator of subglacial entrainment. The second part presents an empirical model of ice flow close to the ice-sheet margin in West Greenland, which relates the character of the clotted ice to subglacial processes at the site.

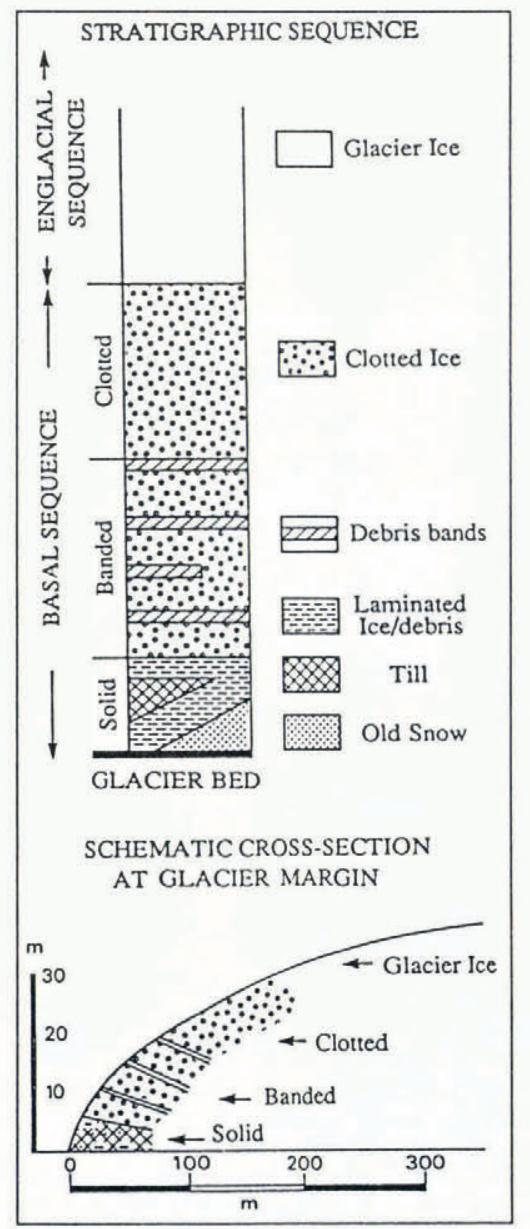

Fig. 1. Stratigraphic relations of facies within the basal ice layer, West Greenland. (After Knight, 1987.) 
The debris-bearing basal-ice layer visible at the margin of the Greenland ice sheet consists of three main stratigraphic units or facies, as shown in Figure 1. At the bottom of the sequence is a layer up to about $5 \mathrm{~m}$ thick, comprising old snow, frozen till and finely laminated ice/ debris layers, frequently in a jumbled and distorted pattern. This is the "solid" basal facies, the origin of which can be attributed to entrainment and deformation of material very close to the margin by over-riding of proglacial material, by freezing-on of water and sediment to the base within a few metres of the margin, and by incorporation of cavity-floor material. Above the solid facies lies the "banded" facies, which can be up to $20 \mathrm{~m}$ thick and comprises layers or bands of debris up to $10 \mathrm{~cm}$ thick, often containing only interstitial ice. The debris bands are separated by layers of cleaner ice up to several metres thick. Banded sequences of this type have been variously attributed to basal freezing-on and to thrusting within the basal ice but no firm consensus has yet been reached (Knight, 1989). Also overlying the solid facies and extending through the banded facies, is a clotted-ice facies. This can be several tens of metres thick and is characterized by lenticular clots of silt and clay distributed through transparent ice. Sugden and others (1987) demonstrated on the basis of sediment size and the isotopic characteristics of the enveloping ice that the clotted-ice sequences originate beneath the interior of the ice sheet, while the banded facies originates at the margin. The clotted ice normally begins directly above, and in contact with, the solid facies. Therefore, folding and thrusting associated with compressive flow at the ice margin means that the banded facies is frequently interdigitated with clotted ice. Almost any combination of facies is possible in the basal-ice sequence; for example, clotted ice may be absent and in such a case, the ice between debris bands may be bubbly glacier ice.

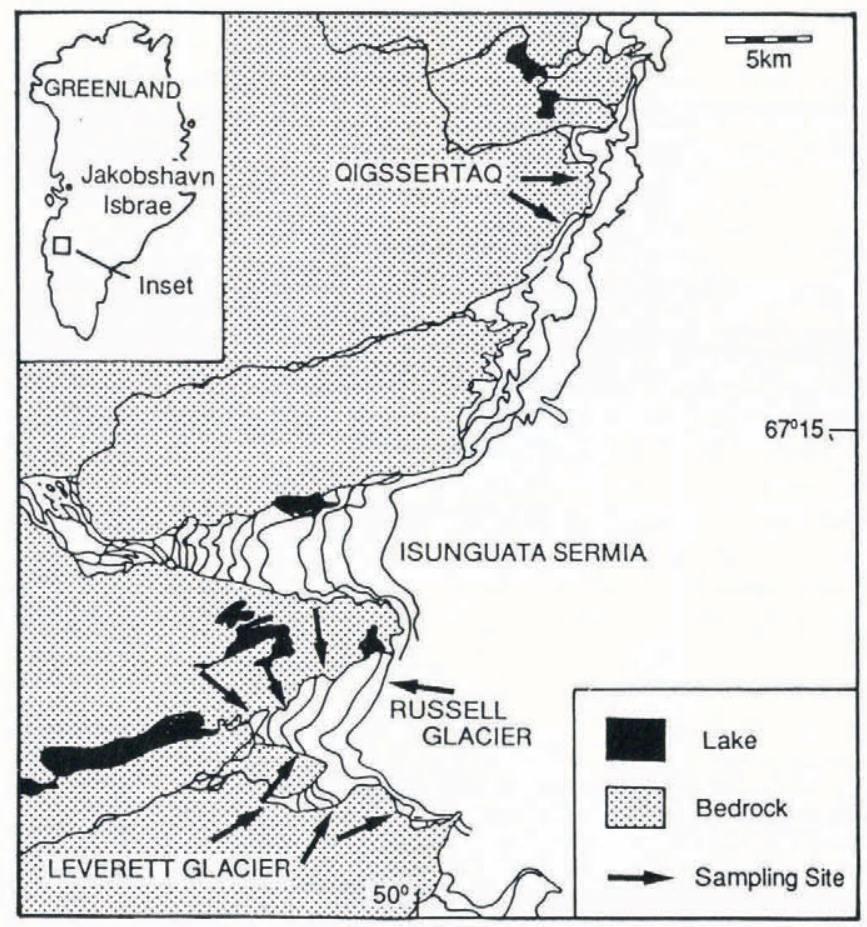

Fig. 2. The western margin of the Greenland ice sheet in the vicinity of Kangerlussuaq.
The observations made by Sugden and others (1987) were largely concentrated at Russell Glacier, the ice margin in the vicinity of Kangerlussuaq, formerly Søndre Strømfjord (Fig. 2). This paper presents results of more detailed work at Russell Glacier but also new observations at Qigssertaq $35 \mathrm{~km}$ to the north and along $10 \mathrm{~km}$ of margin to the southeast of Leverett Glacier. The icesheet margin at Qigssertaq is relatively straight with no major outlet lobes or embayments. In contrast, the margin near Kangerlussuaq is irregular with topographical highs and lows corresponding to a series of glacier lobes and interlobate embayments in the ice margin. The hill summits in the area are at an altitude of about $650 \mathrm{~m}$, while valley bottoms are around $250 \mathrm{~m}$. The main valleys are $5-10 \mathrm{~km}$ apart. Altogether, observations were made over a total of $30 \mathrm{~km}$ of ice-sheet margin. Detailed sediment studies were made at two locations and involved coring and associated stable-isotope analysis. These were supplemented by 30 additional sites where details of the basal-ice layer were recorded. Altogether, about 140 sediment samples were collected and subjected to laboratory analysis for size distribution, particle shape and mineral composition.

\section{THE CLOTTED-ICE FACIES}

\section{Sediment characteristics}

Sedimentary analysis of the ice-marginal sediments at a variety of sites confirmed the conclusions based on the original study at Russell Glacier (Sugden and others, 1987). The large and small clots associated with transparent, bubble-poor ice form a population quite distinct from the debris in the banded and solid basal facies. Figure 3 demonstrates the fine-grained nature of the sediment in the clots and how it differs from the coarser debris bands and the solid basal facies. Thirteen large clots which were excavated and sampled individually (Table 1) are very similar to material obtained from small clots (smaller than $3 \mathrm{~mm}$ in diameter). The material is fine-grained with a mean value of $78 \%$ by weight for the fraction less than $63 \mu \mathrm{m}$ in size and only $5 \%$ for the fraction larger than $250 \mu \mathrm{m}$ in size. Of the 12 clots with sufficient debris to permit further analysis of the fine fraction using a sedigraph, the clay-sized content $(<2 \mu \mathrm{m})$ averaged $9 \%$ by weight, ranging from 1.8 to $19.2 \%$. In contrast, the debris bands at Qigssertaq and Russell Glacier have mean values of only $19 \%$ for the fraction smaller than $63 \mu \mathrm{m}$ and $44 \%$ for the fraction larger than $250 \mu \mathrm{m}$. In addition, clay contents average $1.2 \%$, ranging from nothing to $2 \%$.

Measures of particle shape were made by restricting comparison to the fraction common to both populations, namely, smaller than $63 \mu \mathrm{m}$. The SEM images in Figure 4 show the angular nature of the material in both clots and debris bands. A quantitative count of randomly selected grains using a six-point scale of angularity/roundness revealed no essential difference between the two groups (Fig. 5). Moreover, $52-86 \%$ of the material is either very angular or angular, with $0-16 \%$ rounded or subrounded.

Mineral composition was tackled in two ways. X-ray diffraction was carried out on the clay-sized fraction of 13 


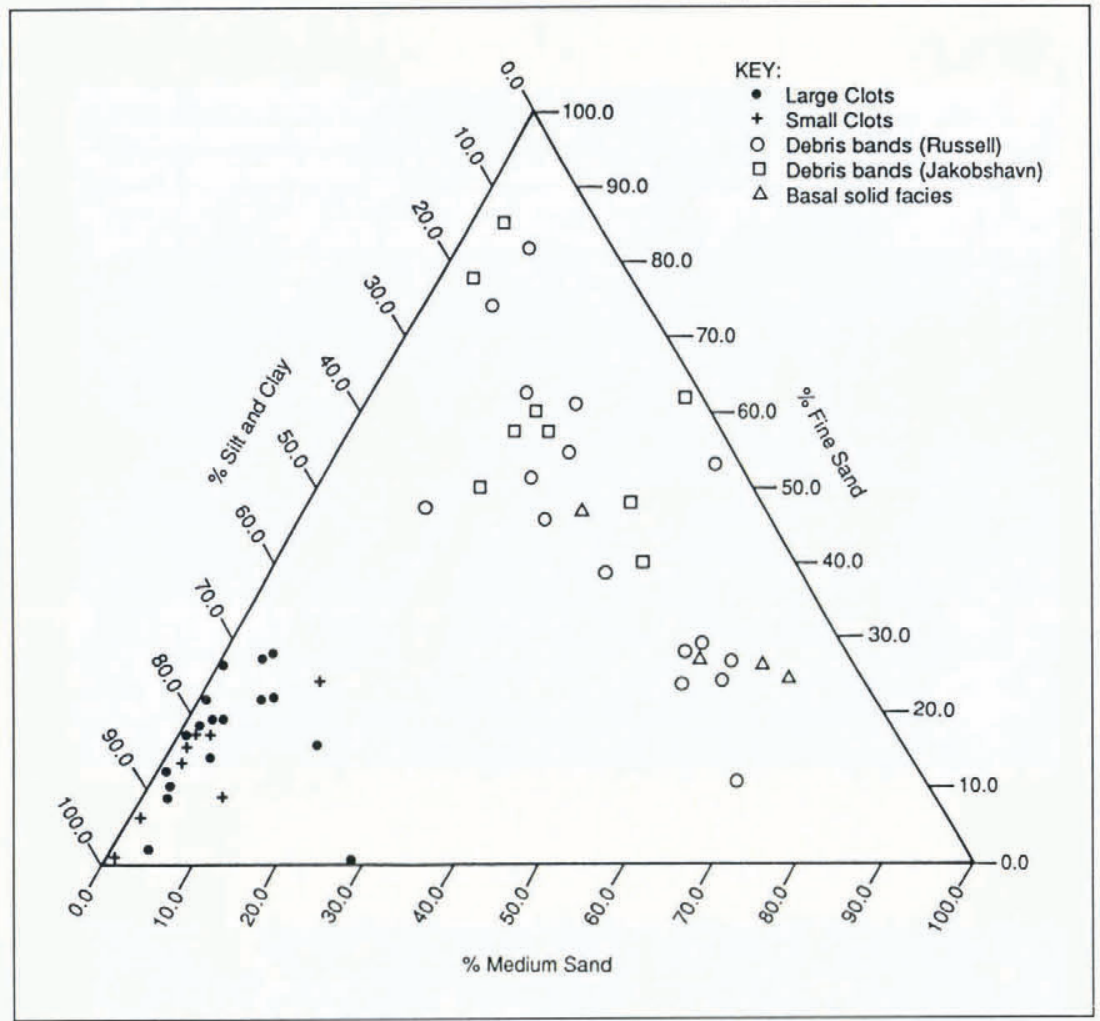

Fig. 3. Particle-size distribution showing the fine material in large clots at Qigssertaq and in small clots in ice above the highest debris band at Russell Glacier. These are compared with the coarser matrix in debris bands at Jakobshavns Isbre, Qigssertaq and Russell Glacier, and basal laminations at four sites southeast of Russell Glacier.

samples of debris bands and the basal solid facies and on 17 samples of large and small clots. All revealed a similar mineral assemblage and one that is characteristic of the gneissic bedrock of Greenland. In an attempt to quantify any differences in mineral composition, we identified mineral abundance in the $63-250 \mu \mathrm{m}$ fraction (Table 2). Quartz, feldspar and mica are dominant with smaller, but significant, occurrences of amphibole, pyroxene and chlorite. The main difference is that the clots have a higher proportion of mica and less quartz than the samesized material in the debris bands and basal solid facies.

The characteristics of the sediment in the clots and the debris bands agree with the earlier conclusions of Sugden and others (1987). Both are the products of subglacial

Table 1. Characteristics of sediment clots at Qigssertaq

\begin{tabular}{|c|c|c|c|c|c|c|}
\hline \multicolumn{2}{|r|}{ Size } & \multirow{2}{*}{$\begin{array}{l}\text { Weight of ice } \\
\text { and sediment } \\
\mathrm{g}\end{array}$} & \multirow{2}{*}{$\begin{array}{c}\text { Weight of } \\
\text { sediment } \\
\mathrm{g}\end{array}$} & \multirow{2}{*}{$\begin{array}{c}>250 \mu m \\
\%\end{array}$} & \multirow{2}{*}{$\begin{array}{c}63-250 \mu m \\
\%\end{array}$} & \multirow{2}{*}{$\begin{array}{c}<63 \mu m \\
\%\end{array}$} \\
\hline & $\mathrm{mm}$ & & & & & \\
\hline & $\times 28 \times 15$ & - & 4.1 & 1.3 & 10.2 & 88.5 \\
\hline $60 \times$ & $\times 50 \times 28$ & - & 38.1 & 1.0 & 18.4 & 80.5 \\
\hline $60 \times$ & $\times 40 \times 20$ & - & 28.1 & 1.4 & 21.3 & 76.7 \\
\hline $50 \times$ & $\times 40 \times 25$ & - & 28.9 & 3.4 & 27.0 & 69.6 \\
\hline & $\times 15 \times 10$ & - & 4.3 & 6.1 & 28.1 & 65.8 \\
\hline $50 \times$ & $\times 40 \times 20$ & - & 25.1 & 2.8 & 19.9 & 77.2 \\
\hline $40 \times$ & $\times 30 \times 20$ & - & 19.3 & 1.7 & 8.6 & 89.3 \\
\hline $20 \times$ & $\times 10 \times 5$ & - & 0.2 & 17.4 & 15.1 & 67.4 \\
\hline $60 \times$ & $\times 40 \times 20$ & - & 31.7 & 5.4 & 26.8 & 67.8 \\
\hline $90 \times$ & $\times 75 \times 60$ & 258 & 59.3 & 5.7 & 13.2 & 81.1 \\
\hline $90>$ & $\times 45 \times 25$ & 105 & 43.5 & 0.2 & 16.8 & 83.0 \\
\hline $85>$ & $\times 40 \times 40$ & 162 & 41.4 & - & - & - \\
\hline $70>$ & $\times 50 \times 40$ & 127 & 48.4 & 0.3 & 25.5 & 73.7 \\
\hline
\end{tabular}



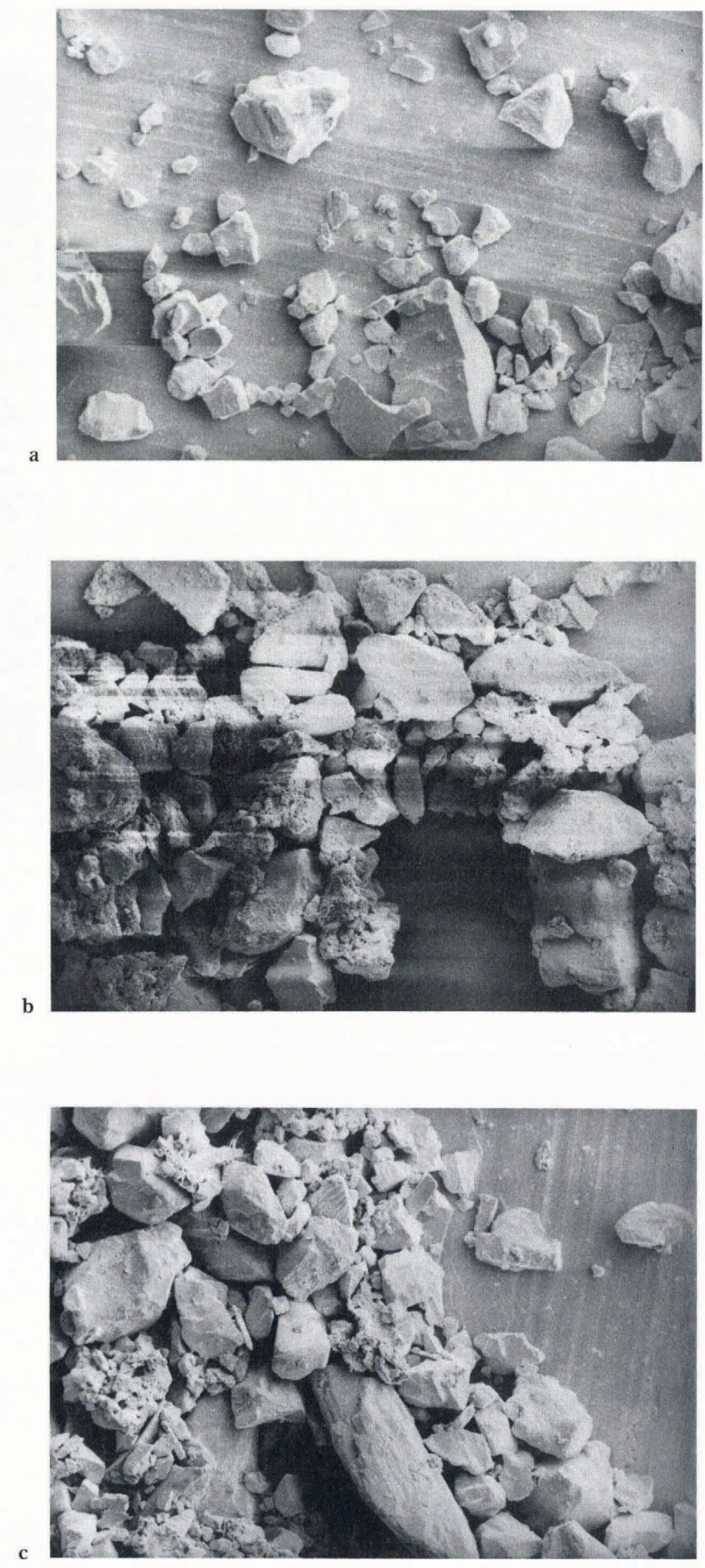

Fig. 4. SEM images of the fractions smaller than $63 \mu \mathrm{m}$ in a debris band at Russell Glacier (above), a large clot at ligssertaq (middle) and a small clot at Russell Glacier (below). The particles are angular and typical of material which has experienced crushing at the base of a glacier. 


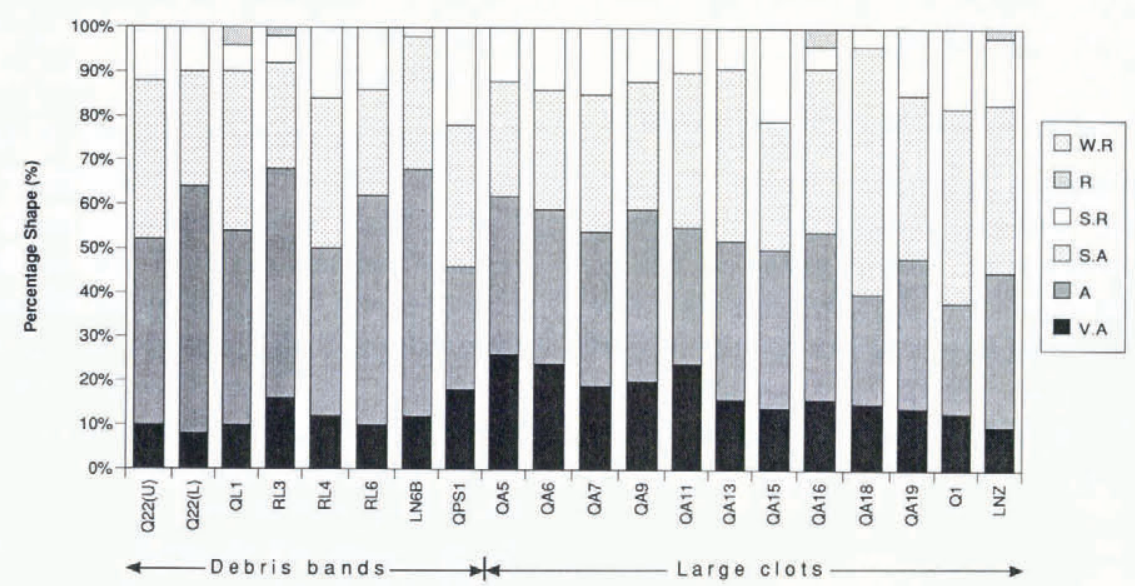

Fig. 5. The angularity of material $<63 \mu \mathrm{m}$ in size from both clots and debris bands. The six-point classification (WR: well-rounded, R: rounded, $S R$ : sub-rounded, $S A$ : sub-angular, A: angular, VA: very angular) is based on the method of Powers (1953). $Q=$ Qigssertaq, $R L=$ Russell Glacier, $L \mathcal{N}=$ Leverett Glacier.

erosion, which accounts for the mineral composition, the angularity due to crushing and the presence of a claysized fraction. However, the clots form in a closed subglacial environment with all the meltwater and debris re-incorporated in the glacier, while the debris bands form near the margin where the fines are washed out by meltwater and there is a selective loss of easily weathered minerals like mica. Further evidence for this contrast between a closed and open environment of basal freezing is provided by the stable-isotope and bubble characteristics of the ice associated with each ice type (Souchez and others, 1990). It is a firm basis from which to argue that the clotted ice is derived from the base beneath the interior of the ice sheet.

Table 2. The mineral composition of 63-250 $\mu$ m sized fraction of clots, debris bands and basal solid facies. The mineral content is consistent with an origin from gneiss. There is more mica in the clots than in the marginal debris bands and basal solid facies. Q, Qigssertaq; R, Russell Glacier; L, Leverett Glacier

\begin{tabular}{|c|c|c|c|c|c|c|c|c|}
\hline & \multirow[t]{3}{*}{ Site } & \multirow{3}{*}{$\begin{array}{c}\text { Quartz } \\
\%\end{array}$} & \multirow{3}{*}{$\begin{array}{c}\text { Mica } \\
\quad \%\end{array}$} & \multirow{3}{*}{$\begin{array}{c}\text { Amphibole } \\
\%\end{array}$} & \multirow{3}{*}{$\begin{array}{c}\text { Pyroxene } \\
\%\end{array}$} & \multirow{3}{*}{$\begin{array}{c}\text { Chlorite } \\
\quad \%\end{array}$} & \multicolumn{2}{|c|}{ Feldspar } \\
\hline & & & & & & & (alkali) & (plagioclase) \\
\hline & & & & & & & $\%$ & $\%$ \\
\hline \multirow[t]{8}{*}{ Large clots } & $Q$ & 47 & 20 & 1 & - & 2 & 32 & 20 \\
\hline & $\widetilde{Q}$ & 50 & 15 & 2 & 2 & 1 & - & 30 \\
\hline & $Q$ & 30 & 20 & 1 & 3 & 1 & 20 & 20 \\
\hline & $\widetilde{Q}$ & 20 & 30 & 1 & 3 & 2 & 29 & 15 \\
\hline & Q & 20 & 19 & 1 & 5 & 5 & 20 & 30 \\
\hline & Q & 25 & 25 & 2 & 1 & 1 & 14 & 32 \\
\hline & $\tilde{Q}$ & 45 & 10 & 1 & 2 & 1 & 21 & 20 \\
\hline & Mean & 34 & 20 & 1 & 2 & 2 & 19 & 24 \\
\hline \multirow[t]{7}{*}{ Debris bands } & Q & 35 & 10 & 5 & 1 & 1 & 20 & 30 \\
\hline & Q & 45 & 5 & - & - & 1 & 15 & 35 \\
\hline & Q & 46 & 2 & - & 2 & - & 10 & 40 \\
\hline & $\widetilde{R}$ & 40 & 5 & 3 & 2 & 1 & 10 & 39 \\
\hline & $\mathrm{R}$ & 40 & - & 2 & 1 & 3 & 15 & 39 \\
\hline & $\mathrm{L}$ & 37 & 12 & 2 & 2 & 3 & 14 & 30 \\
\hline & Mean & 41 & 6 & 2 & 1 & 2 & 14 & 36 \\
\hline \multirow[t]{5}{*}{ Basal solid } & $\mathrm{R}$ & 60 & 10 & 5 & - & - & 5 & 20 \\
\hline & $\mathrm{L}$ & 50 & 15 & 2 & 1 & - & 2 & 20 \\
\hline & $\mathrm{L}$ & 55 & 5 & 5 & 2 & 1 & 5 & 20 \\
\hline & $\mathrm{L}$ & 40 & 5 & 5 & 10 & - & - & 30 \\
\hline & Mean & 51 & 9 & 4 & 3 & 0 & 3 & 23 \\
\hline
\end{tabular}




\section{Variations within the clotted ice}

The clotted-ice facies show several general tendencies:

1. Clot-size variation. Figure 6 shows that the size of debris clots in the clotted ice decreases up-glacier. The biggest clots visible at any site are at the bottom of the clotted ice and there is a gradual decrease in the maximum clot size higher up the sequence. The largest clots near the base of the sequence are several centimetres in diameter (Table 1), while the smallest ones at the top of the sequence may be $<1 \mathrm{~mm}$ in diameter.

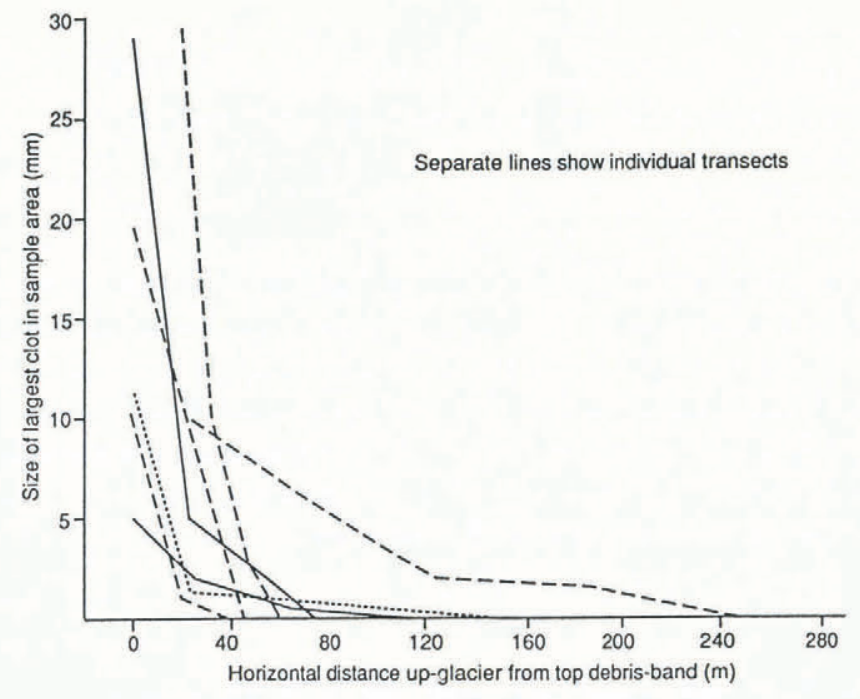

Fig. 6. The decrease in maximum clot size up-sequence. Data from both Qigssertaq and Russell-Leverett Glaciers.

2. Maximum clot size. Figure 7 shows that there is a relationship between the up-glacier extent of the clottedice layer and the size of the largest clots in the layer. At sites where the clotted ice is thick and extends furthest up-

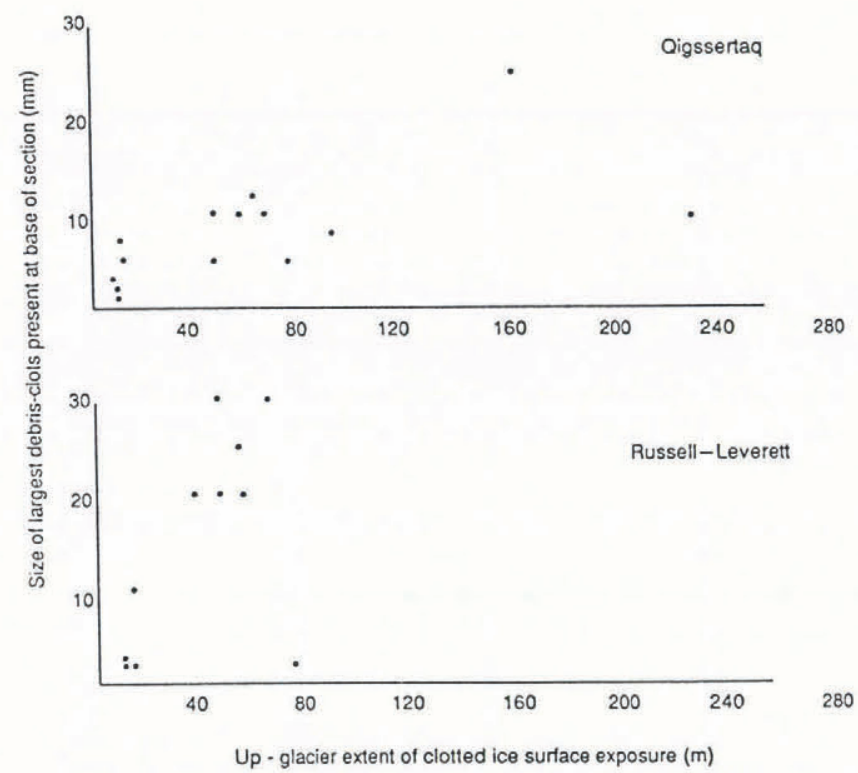

Fig. 7. The correlation between the up-glacier extent of surface exposure of the clotted-ice layer and the size of the largest clots in the layer. The surface exposure of clotted ice at the Russell-Leverett Glaciers sites is limited by the relative steepness of the ice margin compared with the margin at Qigssertaq. glacier, the clots at the base of the layer are larger; where the clotted-ice layer is thin, only small clots exist.

3. Bubble characteristics. Figure 8 illustrates the gradual transition in bubble characteristics up-sequence. At the base of the clotted-ice layer, there are no intra-crystal bubbles and any gas inclusions are in the form of "tubes" along crystal boundaries. Progressively, up-sequence intra-crystal bubbles begin to occur and become larger and more numerous. Towards the top of the sequence, inter-crystal tubes disappear and all visible gas inclusions are in the form of bubbles. These are mostly intra-crystal but some are inter-crystal, as in white bubbly glacier ice. At the point where debris clots are no longer visible, bubble foliation begins to appear, and this defines the top of the clotted ice and the base of unaltered ice. This is a gradual transition rather than a sharp boundary.

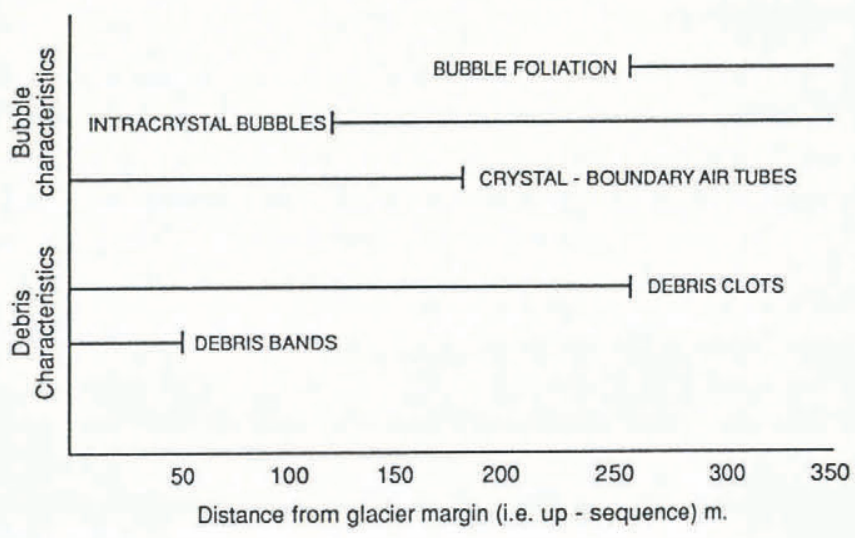

Fig. 8. Chart showing how bubble and debris characteristics in the basal-ice layer vary with distance from the margin.

In summary, up-sequence changes in clot size and bubble characteristics indicate a clotted-ice stratigraphy, whereby clot size decreases up-sequence and the ratio of intra-crystal to inter-crystal bubbles increases. As a result of these changes, the ice becomes cleaner but less transparent up-sequence.

\section{The spatial distribution of the clotted-ice facies}

Figure 9 shows how the principal features of the clottedice facies vary around the margins of Russell and Leverett Glaciers. The clotted ice is least well-developed at the snouts of the two glaciers and at the apex of the interlobe embayment between the two glaciers. The layer is thickest midway along the lateral margins of both glaciers.

\section{DISCUSSION}

The characteristics and spatial variability of the clotted facies suggest that it is modified by some process which affects the base of the clotted ice but not the top part. The top part of the clotted ice does not vary from site to site; there is the same transition from the clotted to unaltered glacier ice, with clot size gradually diminishing to zero, bubble content gradually increasing and bubble foliation 


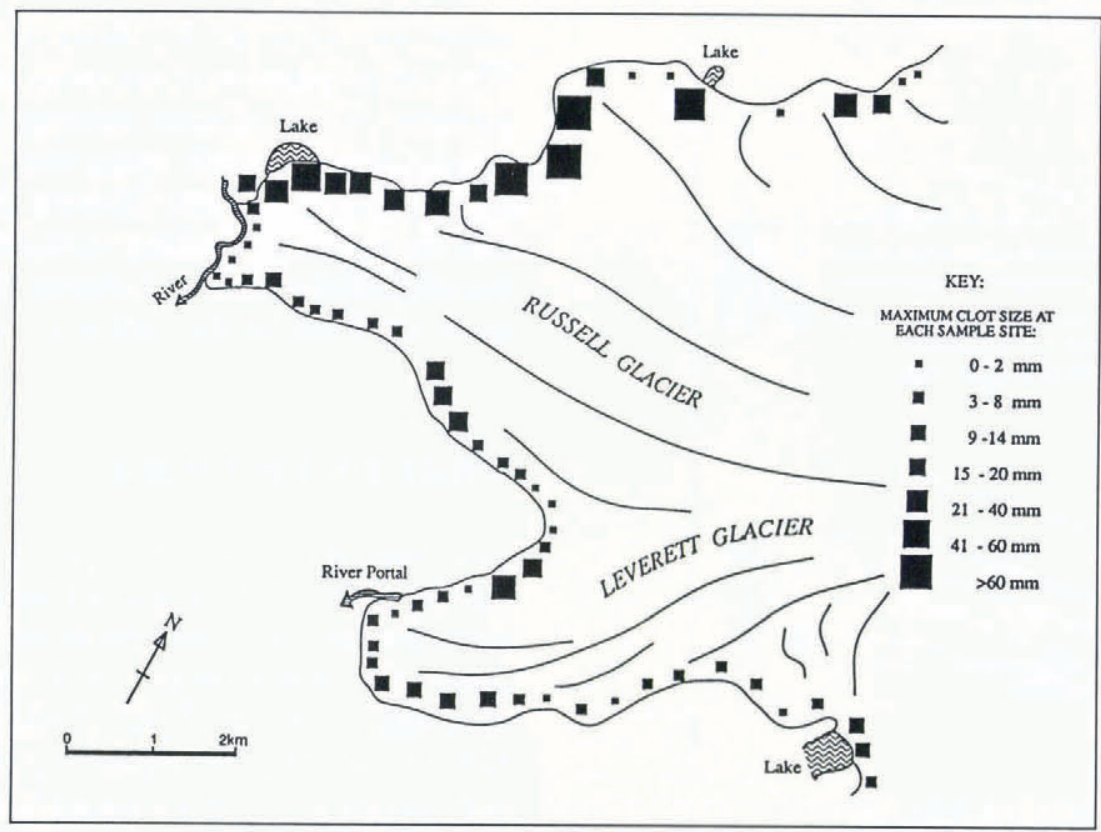

Fig. 9. Variation around the margin of the Russell-Leverett Glaciers in the size of the largest clots present in the basal ice.

beginning. These observations are best explained either by accretion of clotted ice at the base of the layer or by progressive removal of clotted ice from the base of the layer. An interpretation can be offered in the form of a model of ice flow close to the ice-sheet margin. This model comprises two separate glaciological processes, which may act together to produce the observed clotted-ice development.

\section{Ice divergence/convergence}

The ice-sheet margin in West Greenland is characterized by topographic highs and lows, with corresponding glacier embayments and lobes (Fig. 10a). Basal ice layers are diverted around topographic highs with little disturbance of the original stratigraphic order; thus, small clots remain at the top of the sequence and larger clots towards the bottom (Fig. 10b). The effect of this is to create a characteristic distribution of basal-ice layers at the margin such that the lower layers are funnelled into the lobes while only the higher layers remain at the interlobate margins (Fig. 10c). If the amplitude of the topographic high is greater than the thickness of the basal-ice layer, then all the basal ice may be diverted to leave unaltered glacier ice at the interlobate margin. The overall effect is a gradation with glacier lobes characterized by the largest clots, and interlobate margins by the smallest (Fig. 10d).

\section{Basal melting}

Where there is no basal melting, the basal ice sequence in the interior of the ice sheet is preserved as far as the margin, with larger clots at the base and a fining-upwards sequence as described earlier (Fig. 11a). However, where there is basal melting, the lower layers of the basal ice are lost, and only the upper layers survive at the margin (Fig. 11b). The effect of this is to produce a zone of smaller clots at the margin down-glacier of basal melting zones. These

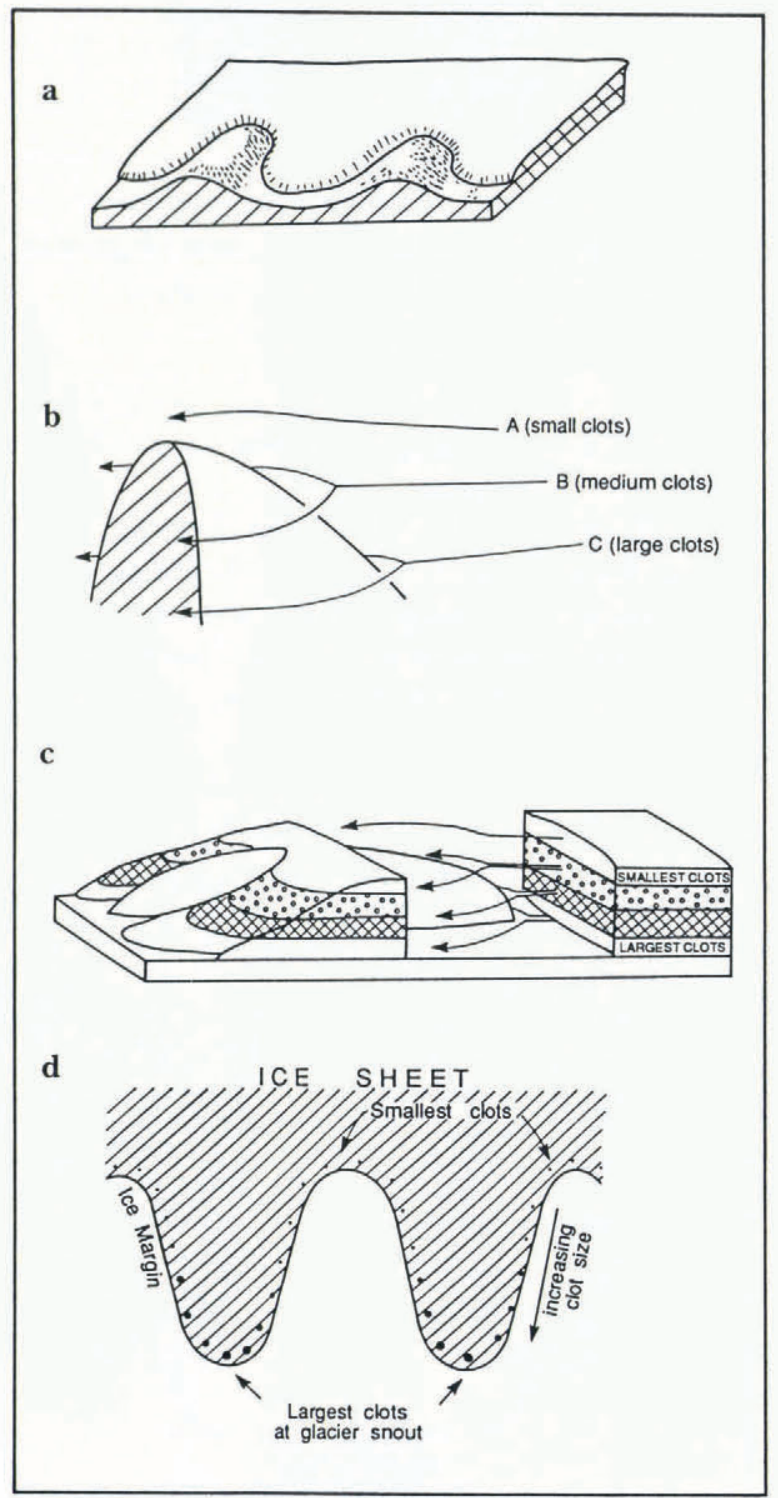

Fig. 10. The effect of divergence/convergence on the thickness of the basal clotted-ice layer. (See text for explanation.) 


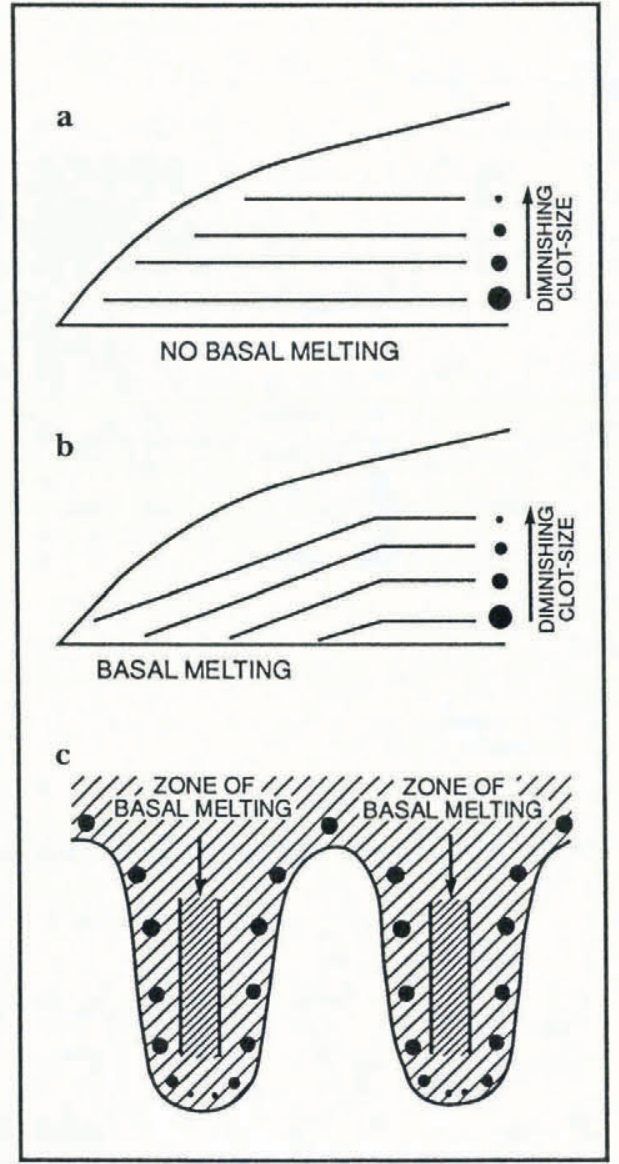

Fig. 11. The effect of basal melting on the thickness of the basal clotted-ice layer. (See text for explanation.)

zones are predominantly in areas of most rapid streaming flow, particularly in the glacier lobes where subglacial meltwater routes are present (Fig. 11c).

Combining both effects gives the pattern shown in Figure 12. Basal-ice-layer thickness and clot size decrease up-glacier around the margin of a lobe as a result of ice divergence and down-glacier as a result of basal melting, so that the largest clots and the thickest basal ice occur

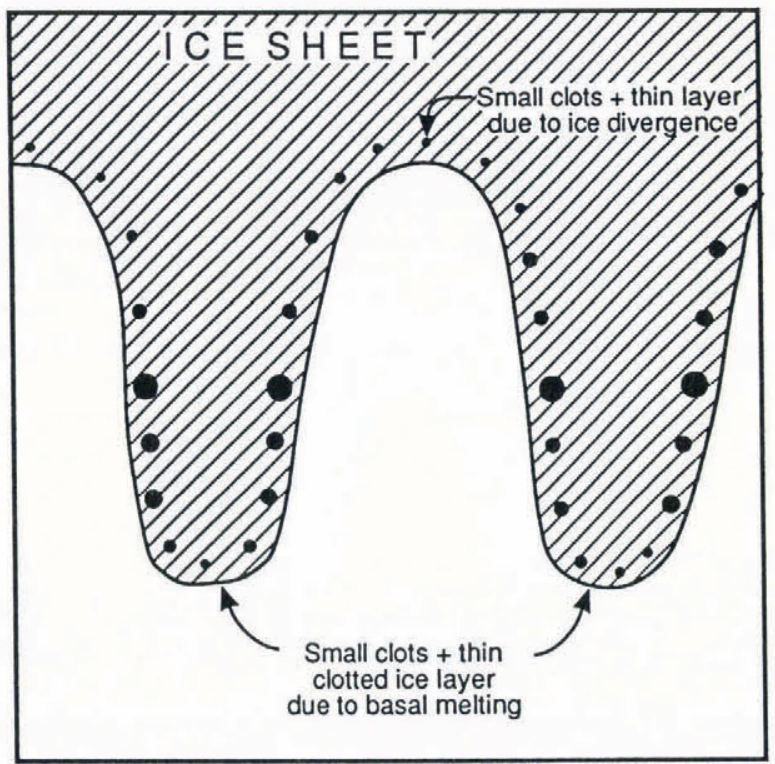

Fig. 12. Variation of clotted-ice characteristics around a lobate glacier margin as predicted by the model. somewhere between the snout and the interlobe apex. The precise position of the areas where the layer is thin depends on the precise location of subglacial melting zones. Comparing this model with the situation observed at Russell and Leverett Glaciers (Fig. 9), it can be seen that the maximum melting zones correspond to the exit of the subglacial stream at Leverett Glacier and the calving snout undercut by the stream at Russell Glacier.

\section{WIDER IMPLICATIONS}

The main point of this paper is that it is possible to identify a basal-ice facies at the edge of the Greenland ice sheet and use its occurrence in ice at the margin to infer processes inland from the ice margin. In the Kangerlussuaq area, the amplitude of the topography of about $400 \mathrm{~m}$ is sufficient to impose a pattern of ice divergence and convergence and associated basal melting at a scale of several kilometres. Recognition of flow irregularities at this scale has several important implications:

1. Diversion of most basal ice around hills is a larger-scale demonstration of an effect already recognized at a scale of metres or tens of metres (Boulton, 1974). The increased flux of ice and debris flowing round a hill, especially when associated with local basal melting, provides a powerful feed-back loop by which ice sheets can deepen existing depressions.

2. Differentiation of the basal load of the ice sheet will occur along the ice margin. Long-distance debris will occur preferentially in the lobate areas, while local material will dominate in interlobate areas. In the absence of significant meltwater activity, one would expect a lithological contrast to be discernible along any marginal moraine with longer-distance debris concentrated in the lobate areas and locally derived material in the interlobate areas. Also, the longer-travelled material in lobate areas will be finer and the total volumes will be higher than local material in interlobate areas. In areas of meltwater activity, this finer, longer-travelled material will be eroded preferentially by subglacial streams.

3. The diversion of ice around topographic highs at the scale of kilometres has implications for the siting of ice cores. Except at the very centre of an ice sheet, it is likely that a core sited above a topographic high will not contain the lowest ice layer.

4. The knowledge of the characteristics of far-travelled basal ice exposed in the margin of the Greenland ice sheet should help in the interpretation of debris-bearing ice at the base of ice cores in Greenland (Herron and Langway, 1979; Koerner, 1989) and Canada (Gemmell and others, 1986). However, it is clearly important to select a site where the most complete sequence may be expected.

Finally, it is important to emphasize that the model developed in this paper is constrained by observation along a relatively restricted length of ice-sheet margin. As such, it can be regarded as no more than an initial hypothesis. We hope, however, that it will prove helpful in guiding further observation which in turn will refine the model. 


\section{ACKNOWLEDGEMENTS}

This work was made possible by grants from the Royal Society and NATO in support of collaborative work with Professor R. Souchez and colleagues, Laboratoire de Géomorphologie, Université Libre de Bruxelles. P. Knight thanks the U.K. Natural Environment Research Council for a studentship which stimulated the original work, and R. Grimes, R. Williams and D. Knight for assistance in the field.

\section{REFERENCES}

Boulton, G. S. 1974. Processes and patterns of glacial erosion. In Coates, D. R., ed. Glacial geomorphology. Binghamton, NY, State University of New York, 41-87.

Gemmell, A.M.D., M.J. Sharp and D. E. Sugden. 1986. Debris from the basal ice of the Agassiz Ice Cap, Ellesmere Island, Arctic Canada. Earth Surface Processes and Landforms, 11(2), 123-130.

Herron, S. and C. C. Langway, Jr. 1979. The debris-laden ice at the bottom of the Greenland ice sheet. F. Glaciol., 23(89), 193-207.

Hubbard, B. and M. Sharp. 1989. Basal ice formation and deformation: a review. Progress in Physical Geography, 13(4), 529-558.
Knight, P. G. 1987. Observations at the edge of the Greenland ice sheet: boundary condition implications for modellers. International Association of Hydrological Sciences Publication 170 (Symposium at Vancouver 1987 - The Physical Basis of Ice Sheet Modelling), 359-366.

Knight, P. G. 1989. Stacking of basal debris layers without bulk freezingon: isotopic evidence from West Greenland. F. Glaciol., 35(120), 214 216.

Koerner, R. M. 1989. Ice core evidence for extensive melting of the Greenland ice sheet in the last interglacial. Science, 244(4907), 964968.

Lawson, D. E. 1979. Sedimentological analysis of the western terminus of the Matanuska Glacier, Alaska. CRREL Rep. 79-9.

Powers, M. C. 1953. A new roundness scale for sedimentary particles. J. Sediment. Petrol., 23, 117-119.

Souchez, R.A. and R.D. Lorrain. 1991. Ice composition and glacier dynamics. Berlin and New York, Springer-Verlag.

Souchez, R. A., M. Lemmens, R. Lorrain, J.-L. Tison, J. Jouzel and D. Sugden. 1990. Influence of hydroxyl-bearing minerals on the isotopic composition of ice from the basal zone of an ice sheet. Nature, 345(6272), 244-246.

Sugden, D.E. and 6 others. 1987. Evidence for two zones of debris entrainment beneath the Greenland ice sheet. Nature, 328(6127), 238-241.

The accuracy of references in the text and in this list is the responsibility of the authors, to whom queries should be addressed. 